\title{
PEMANFAATAN EKSTRAK BIJI KELOR (Moringa oleifera Lamk) \\ DENGAN KULIT ARI SEBAGAI KOAGULAN ZAT WARNA REAKTIF \\ DALAM LARUTAN MODEL LIMBAH CAIR INDUSTRI KAIN BESUREK
}

\section{UTILIZATION OF MORINGA SEED EXTRACT (Moringa oleifera Lamk) WITH THE EPIDERMIS AS A REACTIVE DYE COAGULANT IN A SOLUTION OF "BESUREK" INDUSTRIAL LIQUID WASTE}

\author{
Rahma Hidaiyanti \\ Program Studi Teknologi Pertanian Fakultas Pertanian, Universitas Dehasen Bengkulu
}

\begin{abstract}
ABSTRAK
Penelitian ini dilakukan untuk menentukan kemampuan ekstrak serbuk biji kelor dengan kulit ari sebagai koagulan alami untuk mengurangi kadar zat warna reaktif dalam larutan model limbah cair industri kain besurek. Pada penelitian ini mula-mula serbuk biji kelor dengan kulit ari diekstraksi dengan berbagai persentase serbuk yaitu 3\%, 5\%, dan 7\%, sedangkan variasi waktu pengadukan dalam proses ekstraksi yaitu 30, 45 dan 60 menit dengan suhu ekstraksi $60{ }^{\circ} \mathrm{C}$. Ekstrak biji kelor dengan kulit ari yang dihasilkan kemudian digunakan sebagai koagulan untuk mengurangi kadar zat warna reaktif dalam larutan model limbah cair industri kain besurek. Hasil penelitian menunjukkan bahwa kondisi optimum dari ekstrak serbuk biji kelor dengan kulit ari adalah pada persentase serbuk 5\% dan waktu pengadukan dalam proses ekstraksi 45 menit untuk ketiga zat warna reaktif dengan pengurangan zat warna reaktif biru, merah, dan kuning berturut-turut adalah 491,63 $\mathrm{mg} / \mathrm{mL}, 490,02 \mathrm{mg} / \mathrm{mL}, 466,60 \mathrm{mg} / \mathrm{mL}$.
\end{abstract}

Kata kunci : Moringa oleifera Lamk, koagulasi, ekstraksi, zat warna reaktif

\begin{abstract}
The aim of this research was to determine the ability of merunggai seed powder extract with shelled and non-shelled as a natural coagulant to reducing reactive colours concentration in liquid waste model of industrial besurek. In this research, for the first time merunggai seed powder with shelled and non-shelled was extracted with powder percentage variation of 3\%, $5 \%$ and $7 \%$, while period process of extraction variation were 30 minutes, 45 minutes and 60 minutes at the temperature of extraction $60{ }^{\circ} \mathrm{C}$. Then merunggai seed extract with shelled and non-shelled was used as coagulant to reducing reactive colours concentration in model liquid. The result showed that optimum condition for merunggai seed powder extract with shelled is $5 \%$ powder percentage with period process of extraction during 45 minutes for reactive colours blue, red and yellow. The decrease of reactive colour content were 491,63 $\mathrm{mg} / \mathrm{mL}, 490,02 \mathrm{mg} / \mathrm{mL}$ and 466,60 $\mathrm{mg} / \mathrm{mL}$ respectively.
\end{abstract}

Keywords: Moringa oleifera Lamk, coagulation, extraction, reactive colours 


\section{PENDAHULUAN}

Kain Besurek merupakan salah satu bentuk batik dari hasil kerajinan tradisional daerah Bengkulu yang telah diwariskan secara turun-temurun. Industri kain besurek dalam proses produksinya menggunakan beberapa bahan pewarna, zat warna yang biasa digunakan umumnya zat warna sintetik. Hal ini dikarenakan zat warna sintetik harganya lebih murah dan mempunyai sifat-sifat yang jauh lebih baik daripada zat warna alami, mudah diperoleh dan mempunyai aneka macam warna yang banyak, serta mudah cara pemakaiannya.

Zat warna reaktif merupakan salah satu jenis zat warna sintetik yang digunakan dalam pewarnaan kain besurek. Menurut Sihombing dalam Sutanto (2000), zat warna reaktif tidak terdegradasi secara alamiah di lingkungan dan bersifat karsinogenik sehingga jika masuk ke dalam tubuh manusia akan mengendap secara utuh di dalam hati dan pada akhirnya dapat mengakibatkan kanker hati.

Mengingat besarnya dampak yang ditimbulkan dari limbah cair industri kain besurek khususnya zat warna reaktif, maka perlu dicari cara pengolahan limbah cair industri kain besurek yang tepat dan murah untuk mengurangi atau bahkan menghilangkan zat warna yang ada dalam limbah cair industri kain besurek tersebut, sehingga limbah cair yang dibuang ke perairan bebas tidak mencemari lingkungan.

Biji kelor (moringa oleifera lamk) merupakan salah satu koagulan alami yang dapat digunakan untuk penjernihan air. Dalam biji kelor terkandung senyawa aktif 4- $\alpha$-L-rhamnosyloxybenzil-isotiosianat yang mampu mengadopsi dan menetralisir partikel logam dalam air limbah dan partikel kotoran yang melayang di dalam air (Arung, 2002). Pemanfaatan biji kelor sebagai koagulan dari segi biaya lebih ekonomis dan efisien. Selain itu, juga bersifat biodegradable sehingga akan ramah lingkungan dibandingkan jika menggunakan koagulan dari bahan kimia seperti tawas. Bahkan, biji kelor juga berkhasiat sebagai antibakteri. Sutherland dkk. (1994), memanfaatkan biji kelor sebagai koagulan untuk mengurangi kekeruhan dalam air. Dari hasil penelitian tersebut ternyata serbuk biji kelor mampu mengurangi kekeruhan air yang mulamula 270-380 NTU berkurang menjadi 4 NTU (Nephelometric Turbidity Unit). Menurut penelitian Chandra dalam rrionline.com, biji kelor dapat dimanfaatkan sebagai bahan koagulan (bioflokulan) sewaktu mengolah limbah cair pabrik tekstil. Hasilnya terjadi degradasi warna hingga 98 persen. 
Menurut Dwirianti (2005), pemanfaatan biji kelor dengan kulit mempunyai kemampuan yang lebih baik untuk menurunkan kekeruhan pada air dibandingkan dengan menggunakan biji kelor tanpa kulit. Hal ini kemungkinan di dalam kulit biji kelor juga terkandung zat senyawa aktif 4- $\alpha$-L-rhamnosyloxybenzil-isotiosianat. Pemanfaatan Biji kelor pada umumnya berbentuk serbuk. Disamping itu, biji kelor juga dapat dimanfaatkan dengan cara mengekstrak zat aktif yang terkandung dalam biji buah kelor dengan menggunakan pelarut tertentu. Salah satu pelarut yang dapat digunakan yaitu pelarut air. Pemanfaatan ekstrak biji kelor sebagai koagulan telah dilakukan antara lain oleh Lestari (2008) yang menguji efektifitas ekstrak biji kelor sebagai koagulan ion besi terlarut dalam air. Dari penelitian tersebut ternyata ekstrak biji kelor mampu mengurangi kadar ion besi sebesar 2933,01 mg/mL ekstrak biji kelor. Mufrihan (2008) menguji efektifitas ekstrak biji kelor sebagai koagulan ion mangan terlarut dalam air. Ternyata ekstrak biji kelor mampu mengurangi kadar ion mangan sebesar 955,6 mg/mL ekstrak biji kelor.

Berdasarkan penelitian-penelitian tersebut kemungkinan biji kelor juga dapat digunakan sebagai salah satu alternatif untuk mengurangi kadar zat warna reaktif dalam larutan model limbah cair industri kain besurek.

\section{METODE PENELITIAN}

\section{Alat dan Bahan}

Alat-alat yang digunakan dalam penelitian ini meliputi Spektronik 20 Milton-Roy, hotplate, kuvet, neraca analitik, termometer, pengaduk magnet, alat gelas, stopwatch, kertas What-man 42, aluminium foil dan batang pengaduk.

Sedangkan bahan yang digunakan meliputi biji kelor dengan kulit ari, akuades serta serbuk zat warna reaktif berwarna merah, kuning, dan biru.

\section{Prosedur Penelitian}

\section{Preparasi sampel}

Biji buah kelor diambil di kota Bengkulu. Sampel diambil dengan memetik buah kelor yang sudah tua. Buah kelor dipisahkan dari kulit buahnya kemudian dijemur sampai kering. Selanjutnya biji kelor dengan kulit ari digerus secara terpisah hingga menjadi serbuk, dan siap digunakan untuk proses selanjutnya.

\section{Ekstraksi senyawa aktif biji kelor}

Diambil serbuk biji kelor dengan kulit ari sebanyak 3, 5 dan $7 \mathrm{~g}$ masing-masing dimasukkan ke dalam gelas piala yang berbeda kemudian ditambahkan akuades sampai $100 \mathrm{~mL}$, selanjutnya campuran dipanaskan dengan menggunakan hotplate 
pada suhu $\pm 60{ }^{\circ} \mathrm{C}$ (Lestari, 2008), sambil diaduk pada waktu pengadukan selama 30; 45 dan 60 menit. Selanjutnya dilakukan proses penyaringan sehingga diperoleh ekstrak senyawa aktif dari biji kelor dengan kulit ari yang siap digunakan sebagai koagulan untuk zat warna reaktif.

\section{Pembuatan larutan model induk zat warna reaktif 1000 ppm}

Ditimbang 0,1 g dari setiap zat warna reaktif yang digunakan kemudian dimasukkan ke dalam labu ukur $100 \mathrm{~mL}$. Selanjutnya ditambahkan dengan akuades sampai tanda batas dan dikocok sampai larut sempurna. Kemudian untuk mendapatkan larutan model zat warna 100 ppm yang digunakan dalam penelitian ini dilakukan dengan cara pengenceran dari larutan induk. Prosedur di atas dilakukan dengan menggunakan sampel zat warna reaktif merah, biru, dan kuning.

\section{Penentuan panjang gelombang ( $\lambda$ )} serapan maksimum zat warna reaktif

Sebelum dilakukan pengukuran daya koagulasi ekstrak biji kelor yang dihasilkan terhadap zat warna reaktif kain besurek, terlebih dahulu dilakukan optimasi untuk memilih panjang gelombang serapan maksimum terhadap 3 macam zat warna dasar kain besurek yaitu merah, kuning, dan biru. Optimasi dilakukan dengan mengukur serapan dari masing-masing zat warna dengan konsentrasi 5 ppm untuk setiap zat warna pada panjang gelombang 400-600 nm, selanjutnya dibuat kurva hubungan antara absorbansi dan panjang gelombang sehingga akan diperoleh panjang gelombang yang menunjukkan serapan yang paling besar untuk setiap zat warna. Kemudian panjang gelombang maksimum ini akan digunakan untuk mengukur absorbansi larutan zat warna reaktif setelah proses koagulasi oleh ekstrak biji kelor.

\section{Pembuatan kurva kalibrasi}

Kurva standar atau kurva kalibrasi merupakan kurva hubungan antara absorbansi dengan konsentrasi larutan standar zat warna pada panjang gelombang serapan maksimumnya. Pembuatan kurva ini dilakukan dengan cara membuat larutan zat warna dengan konsentrasi 2; 4; 6; 8 dan 10 ppm yang dibuat dengan cara pengenceran dari larutan induk zat warna reaktif. Pada proses ini larutan blanko yang digunakan adalah akuades. Kemudian dari berbagai konsentrasi larutan zat warna reaktif diukur absorbansinya pada panjang gelombang serapan maksimumnya. Selanjutnya dibuat kurva hubungan antara absorbansi dengan konsentrasi larutan zat warna reaktif (Day dan Underwood, 1999). 
Penentuan kemampuan ekstrak biji kelor dengan kulit ari untuk mengurangi kadar zat warna reaktif

Diambil $2 \mathrm{~mL}$ ekstrak biji kelor dengan kulit ari kemudian dimasukkan dalam gelas piala berbeda, lalu tambahkan dengan $10 \mathrm{~mL}$ larutan zat warna reaktif yang konsentrasinya 100 ppm, diaduk selama 20 menit kemudian didiamkan agar mengendap, selanjutnya larutan disaring agar filtrat terpisah dari endapannya dan filtrat yang dihasilkan diukur volumenya. Kemudian filtrat zat warna reaktif diukur absorbansinya secara spektrofotometri pada panjang gelombang maksimum yang telah diketahui sebelumnya. Untuk menentukan konsentrasi sampel zat warna dilakukan dengan cara mengintrapolasikan absorbansi zat warna hasil dari pengukuran pada kurva kalibrasi yang telah dibuat. Kemampuan ekstrak biji kelor dengan kulit ari sebagai koagulan terhadap zat warna reaktif ditentukan dari selisih antara banyaknya zat warna reaktif mula-mula dengan banyaknya zat warna reaktif setelah proses koagulasi yang dinyatakan dalam $\mathrm{mg} / \mathrm{mL}$ ekstrak biji kelor, yang secara matematis dirumuskan sebagai berikut.

$$
\text { Pengurangan Zat Warna }=\frac{\mathrm{Xo}-\mathrm{Xt}}{\mathrm{Z}}
$$

Keterangan :

Xo: Banyaknya zat warna reaktif mula- mula

Xt : Banyaknya zat warna reaktif sesudah proses koagulasi

Z: Volume ekstrak biji kelor yang digunakan

Prosedur di atas berlaku untuk zat warna reaktif

\section{HASIL DAN PEMBAHASAN}

\section{Kurva Kalibrasi Zat Warna Reaktif}

Kurva hubungan antara absorbansi dengan konsentrasi larutan standar zat warna reaktif terlihat seperti pada Gambar 1.

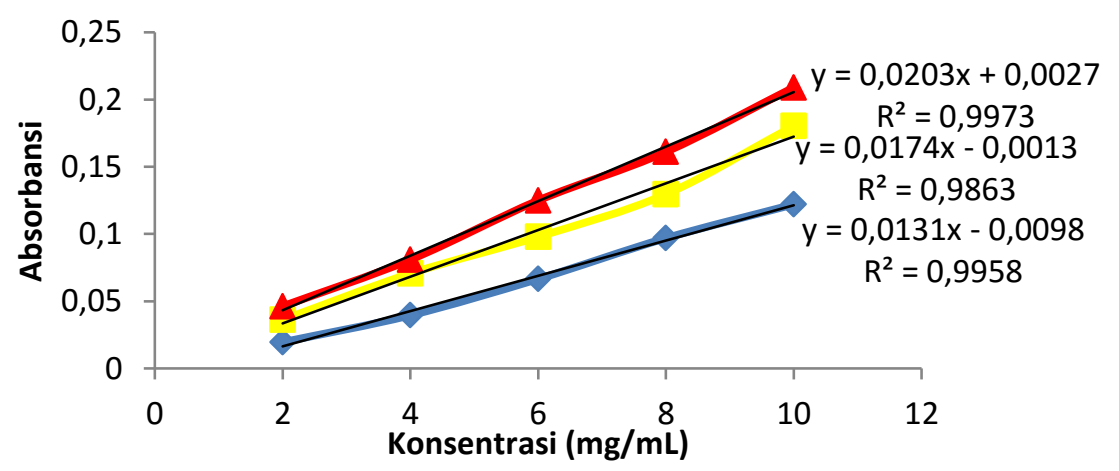

Gambar 1. Kurva kalibrasi zat warna reaktif 
Kemampuan ekstrak biji kelor dengan kulit ari untuk mengurangi kadar zat warna reaktif pada berbagai persentase serbuk biji kelor

Untuk menentukan pengaruh persentase serbuk biji kelor dengan kulit ari maka digunakan variasi persentase serbuk biji kelor yaitu $3 \%, 5 \%$, dan $7 \%$ pada suhu ekstraksi $60^{\circ} \mathrm{C}$ (Lestari, 2008) dan waktu pengadukan dalam proses ekstraksi dibuat tetap yaitu selama 30 menit. Hasil yang diperoleh dapat dilihat pada Gambar 2.

Dari Gambar 2 terlihat bahwa semakin besar persentase serbuk biji kelor maka senyawa aktif yang terkandung dalam serbuk biji kelor semakin banyak sehingga kemampuan ekstrak biji kelor untuk mengurangi zat warna reaktif juga semakin besar dan mencapai optimum pada persentase serbuk biji kelor dengan kulit ari sebesar 5\% untuk ketiga macam zat warna reaktif, kemudian menurun pada persentase serbuk $7 \%$.

Pada persentase serbuk 3\% senyawa aktif yang dihasilkan dari ekstrak biji kelor lebih sedikit dari jumlah yang dibutuhkan untuk mengendapkan ketiga zat warna reaktif sehingga kemampuan dalam pengurangan kadar ketiga zat warna reaktif lebih sedikit. Pada persentase serbuk 5\% senyawa aktif yang terekstrak dari serbuk biji kelor dengan kulit ari mempunyai jumlah yang seimbang dengan jumlah yang dibutuhkan untuk mengendapkan zat warna reaktif dalam larutan model limbah cair industri kain besurek, sehingga senyawa aktif dari ekstrak biji kelor dengan kulit ari yang dihasilkan mampu berinteraksi dengan zat warna reaktif dalam larutan model limbah cair industri kain besurek secara maksimal membentuk mikroflok. Mikroflokmikroflok tersebut cenderung untuk bersatu dan membentuk makroflok atau gumpalan yang lebih besar dan akhirnya mengendap. Akibatnya endapan yang terbentuk pun lebih banyak. Hal ini sesuai yang dikatakan Muyibi dan Evison dalam Dwirianti (2005), yang menyatakan bahwa jika jumlah optimum dari biji kelor sebanding dengan ukuran partikel tersuspensi maka partikel berukuran kecil akan menghasilkan massa flok yang lebih besar. Pada persentase serbuk 7\% kemampuan ekstrak biji kelor mengalami penurunan dalam proses koagulasi zat warna reaktif. Hal ini disebabkan karena senyawa aktif yang dihasilkan jumlahnya melebihi dari jumlah yang diperlukan untuk mengendapkan zat warna, sehingga senyawa aktif dari ekstrak biji kelor yang berlebih akan menyebabkan terjadinya restabilisasi partikel yang telah didestabilisasi. Akibatnya endapan yang telah terbentuk akan terlarut kembali dalam larutan model, sehingga zat warna yang diendapkan semakin sedikit (Mayubi dan Evison dalam Dwirianti, 2005). 


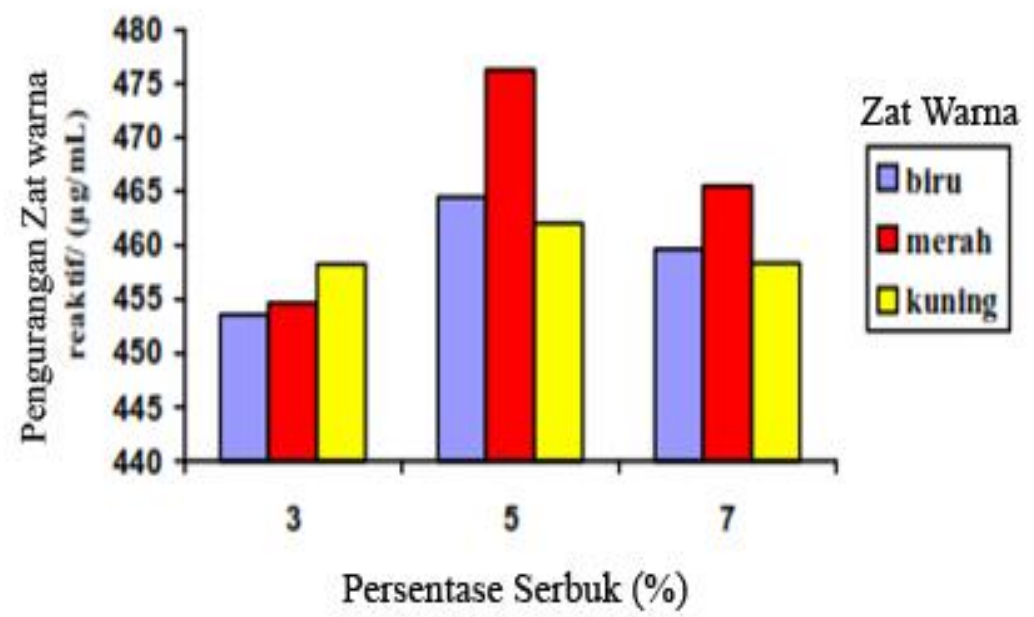

Gambar 2. Kurva hubungan pengaruh variasi persentase serbuk biji kelor dengan kulit ari terhadap pengurangan zat warna reaktif

Kemampuan ekstrak biji kelor dengan

kulit ari untuk mengurangi kadar zat warna reaktif pada berbagai waktu pengadukan dalam proses ekstraksi

Gambar 3 memperlihatkan pengaruh waktu pengadukan terhadap daya serap biji kelor dengan kulit ari untuk mengurangi limbah zat warna reaktif.

Dari Gambar 3 dapat dilihat bahwa semakin lama waktu pengadukan dalam proses ekstraksi kemampuan ekstrak biji kelor dengan kulit ari untuk mengurangi ketiga zat warna reaktif makin besar dan mencapai kondisi optimum pada waktu pengadukan 45 menit dengan pengurangan zat warna sebesar 491,72 $\mu \mathrm{g} / \mathrm{mL}$ zat warna biru; 490,02 $\mu \mathrm{g} / \mathrm{mL}$ untuk zat warna merah dan $466,60 \mu \mathrm{g} / \mathrm{mL}$ zat warna kuning. Pada waktu pengadukan 60 menit dalam proses ekstraksi kemampuan ekstrak biji kelor dengan kulit ari mengalami penurunan dalam mengendapkan ketiga zat warna reaktif dengan pengurangan masingmasing zat warna sebesar $473,55 \mu \mathrm{g} / \mathrm{mL}$ untuk zat warna biru, $477,55 \mu \mathrm{g} / \mathrm{mL}$ zat warna merah dan $463,71 \mu \mathrm{g} / \mathrm{mL}$ zat warna kuning.

Pada waktu pengadukan 30 menit dalam proses ekstraksi kemungkinan senyawa aktif biji kelor dengan kulit ari yang terekstrak sedikit, sehingga belum mencukupi kebutuhan untuk mengendapkan ketiga zat warna reaktif dengan maksimum. Pada waktu pengadukan 45 menit dalam proses ekstraksi senyawa aktif biji kelor dengan kulit ari yang terekstrak 
jumlahnya sebanding dengan yang dibutuhkan untuk mengendapkan ketiga zat warna reaktif, sehingga interaksi antara senyawa aktif biji kelor dengan zat warna reaktif mampu mengendapkan zat warna reaktif secara optimal. Hal ini disebabkan karena dengan penambahan koagulan ekstrak biji kelor ke dalam larutan model zat warna reakif menyebabkan terjadinya destabilisasi partikel koloid dengan maksimal yang membentuk flok-flok kecil. Flok-flok kecil tersebut secara perlahan akan menyatu dan membesar membentuk gumpalan yang besar dan akhirnya mengendap. Akibatnya endapan yang terbentuk lebih banyak. Namun kemampuan ekstrak biji kelor dengan kulit ari untuk mengurangi kadar ketiga zat warna reaktif mengalami penurunan pada waktu pengadukan 60 menit dalam proses ekstraksi. Keadaaan ini disebabkan karena pada waktu pengadukan 60 menit dalam proses ekstraksi senyawa aktif yang dihasilkan kemungkinan melebihi dari jumlah yang dibutuhkan untuk mengendapkan ketiga zat warna reaktif sehingga menyebabkan terjadinya restabilisasi partikel yang menyebabkan endapan yang telah terbentuk akan melarut kembali dalam larutan model zat warna reaktif. Akibatnya larutan menjadi lebih keruh dan endapan yang terbentuk menjadi lebih sedikit. (Mayubi dan Evison dalam Dwirianti, 2005).

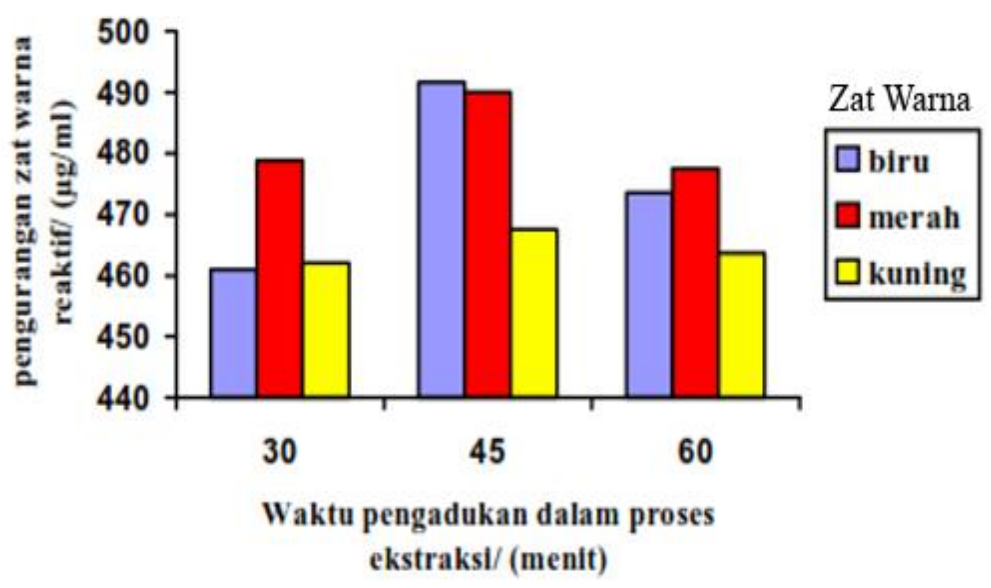

Gambar 3. Kurva hubungan pengaruh variasi waktu pengadukan dalam proses ekstraksi serbuk biji kelor dengan kulit ari terhadap pengurangan zat warna reaktif 
Dari Gambar 3 terlihat bahwa zat warna reaktif merah, biru, dan kuning mengalami perbedaan dalam pengurangan zat warna. Hal ini kemungkinan disebabkan karena ketiga macam zat warna tersebut memiliki berat molekul dan jari-jari molekul yang berbeda (Setiawan dkk., 2004). Dimana menurut Manurung dkk., (2004) zat warna reaktif yang memiliki berat molekul dan jari-jari molekul kecil daya serap terhadap serat relatif kecil, sehingga zat warna yang tidak bereaksi dengan serat mudah dilepaskan atau dihilangkan dibandingkan dengan zat warna yang memiliki jari-jari molekul yang lebih besar.

\section{KESIMPULAN}

1. Ekstrak dari serbuk biji kelor dengan kulit ari dapat dimanfaatkan sebagai koagulan alami untuk mengurangi kadar zat warna reaktif dalam larutan model limbah cair industri kain besurek.

2. Kemampuan ekstrak biji kelor dengan kulit ari untuk mengurangi kadar zat warna reaktif semakin besar pada waktu pengadukan yang makin lama dalam proses ekstraksi dan mencapai optimum pada waktu pengadukan 45 menit untuk ketiga zat warna reaktif kemudian menurun pada waktu pengadukan 60 menit. Pada kondisi ini pengurangan zat warna reaktif biru, merah, dan kuning berturut-turut adalah sebesar 491,63 $\mathrm{mg} / \mathrm{mL}, \quad 490,02$ $\mathrm{mg} / \mathrm{mL}$, dan 466,60 $\mathrm{mg} / \mathrm{mL}$ dengan persentase pengurangan $98,34 \%, 98,0 \%$ dan $93,32 \%$.

\section{DAFTAR PUSTAKA}

Arung. 2002. Terobosan (Biji Kelor Sebagai Penjernih Air Sungai). Harian Umum Suara Merdeka. http ://www. terranet. or. Id / goto berita . php ? id = 5779. [16 Maret 2008]

Day, R.A dan Underwood. 1999. Analisis kimia kuantitatif. Erlangga. Jakarta.

Dwirianti, D. 2005. Penggunaan Biji Moringa Oleifera Lam Dan Membran Mikrofiltrasi Sebagai Alternatif Pengolahan Lindi. Jurnal kimia lingkungan Vol.7., No.1.

Lestari, T. 2008. Efektifitas Ekstraksi Senyawa Bioaktif dari Biji Kelor (Moringa oleifera Lam.) sebagai Koagulan Ion Besi Terlarut dalam Air. [Skripsi]. FMIPA UNIB. Bengkulu.

Manurung, R., Rosdaneli, H., dan Irvan. 2004. Perombakan Zat Warna Azo Reaktif Secara Anaerob Aerob. Jurusan teknik Kimia Universitas Sumatera Utara.

Mufrihan. 2008. Efektifitas Ekstraksi Senyawa Bioaktif dari Biji Kelor (Moringa oleifera Lam.) sebagai Koagulan Ion Mangan dalam Air. [Skripsi]. FMIPA UNIB. Bengkulu

Sutherland, J.P., Folkard, G.K, dan Grant, W.D. 1994. Moringa Oleifera as a Natural Coagulant, papar, 20 th WEDC Conference Affordable Water Supply And Sanitation, Colombo, Sri Lanka

Setiawan, Wilosos, Soleha, Barliati, dan Anggraeni. 2004. Peningkatan 
Daya Serap Sorben Serbuk Gergaji Dengan Pengsulfonasian Dan Pengujiannya Dengan Zat Warna Tekstil Kationik. Jurnal Penelitian Kimia Universitas Sebelas Maret. Surakarta.
Sutanto, T.D. 2000. Laporan penelitian Pemisahan Zat Warna Limbah Cair Industri Kain Besurek Dengan Zeolit Alam Yang Diaktifkan. Lembaga Penelitian Universitas Bengkulu. 